Mérő, T. O., A. Žuljević, K. Varga, and S. Lengyel. 2020. Wing-size related habitat choice of Great Reed Warbler females: the role of habitat quality and management. Avian Conservation and Ecology 15(1):22. https://doi.org/10.5751/ACE-01571-150122

Copyright (C) 2020 by the author(s). Published here under license by the Resilience Alliance.

Research Paper

\title{
Wing-size related habitat choice of Great Reed Warbler females: the role of habitat quality and management
}

\author{
Thomas O. Mérö ${ }^{1,2}$, Antun Žuljević ${ }^{2}$, Katalin Varga ${ }^{3}$ and Szabolcs Lengyel ${ }^{1}$ \\ ${ }^{1}$ GINOP Sustainable Ecosystems Group, Department of Tisza Research, Danube Research Institute, Centre for Ecological \\ Research, Hungary, ${ }^{2}$ Nature Protection and Study Society - NATURA, Serbia, ${ }^{3}$ Bavarian State Institute of Forestry, Freising, \\ Germany
}

\begin{abstract}
Intersexual differences in habitat choice can arise if males and females differ in morphology, physiology, niche partitioning, or resource use, and can be influenced by variation in habitat structure, quality, and management. To better understand such intersexual differences, we studied habitat choice in female Great Reed Warblers (Acrocephalus arundinaceus), a long-distance migrant flagship species of lowland Palearctic reed (Phragmites australis) habitats. We compared wing length, a widely used proxy for individual quality in passerines, of females nesting in six types of differently managed reed habitats. Our dataset on 391 females nesting in 32 sites over 10 years showed that wing length was significantly greater in mining ponds and medium-sized canals than on large canals. Wing length was negatively related to water level fluctuation and females showed strong philopatry to the habitat type in which they were first captured. In comparison to our previous study on male habitat choice, this study found differences in habitat choice between the sexes. Although long-winged individuals in both sexes preferred habitats with stable water and avoided small canals, longer-winged males preferred large canals with little or no management, whereas long-winged females preferred medium-sized canals with some management. Although these results provide some support for intersexual niche segregation, it is also possible that long-winged females avoid large canals, in which nest parasitism by Cuckoos (Cuculus canorus) is frequent, and/or prefer managed, sparse reed beds with better maneuverability for foraging. Our studies suggest that males may primarily choose habitats with abundant old reed and singing perches, whereas females are less sensitive to environmental variation and may choose nest sites based on male quality or territory quality. For conservation, our studies imply that the maintenance of stable water levels, a low intensity of management and the elimination of Cuckoo perches are likely to benefit both long-winged males and females.
\end{abstract}

\section{Sélection d'habitat lié à la longueur de l'aile chez les Rousserolles turdoïdes femelles : le rôle de la qualité de l'habitat et de l'aménagement}

RÉSUMÉ. Des différences dans la sélection d'habitat liées au sexe peuvent s'observer si les mâles et les femelles diffèrent en termes de morphologie, de physiologie, de différenciation de niche ou d'utilisation des ressources, et peuvent être influencées par la variation de structure, de qualité et de l'aménagement de l'habitat. Pour mieux comprendre ce type de différences intersexuelles, nous avons étudié la sélection d'habitat chez la femelle Rousserolle turdoïde (Acrocephalus arundinaceus), espèce-phare migratrice de longue distance occupant des milieux paléarctiques de basses terres dominées par le roseau (Phragmites australis). Nous avons comparé la longueur de l'aile, un indicateur très utilisé pour attester de la qualité individuelle des passereaux, de femelles nichant dans six types de milieux de roseaux aménagés de façon différente. Notre jeu de données, comportant 391 femelles nicheuses à 32 sites sur une période de 10 ans, a révélé que la longueur de l'aile était considérablement plus grande chez les femelles occupant les étangs miniers et les canaux de largeur moyenne, comparativement à celles occupant les grands canaux. La longueur de l'aile était négativement liée aux fluctuations du niveau d'eau et les femelles ont montré une forte philopatrie au type de milieu dans lequel elles avaient été capturées la première fois. Comparativement à notre étude précédente portant sur la sélection d'habitat chez les mâles, la présente étude a fait état de différences selon le sexe dans la sélection d'habitat. Même si les individus aux longues ailes chez les deux sexes ont préféré les milieux montrant un niveau d'eau stable et évité les petits canaux, les mâles aux ailes plus longues ont préféré les grands canaux peu ou non aménagés, tandis que les femelles aux ailes longues ont préféré les moyens canaux un peu aménagés. Bien que ces résultats corroborent jusqu'à un certain point une différenciation de niche fondée sur le sexe, il est aussi possible que les femelles aux longues ailes évitent les canaux larges, dans lesquels le parasitisme de nids par les coucous (Cuculus canorus) est fréquent, et/ou préfèrent les îlots de roseaux épars et aménagés, qui permettent de manoeuvrer plus facilement pour chercher la nourriture. Nos études laissent croire que les mâles sélectionnent peutêtre d'abord les milieux comprenant de nombreux vieux roseaux et des perchoirs desquels chanter, tandis que les femelles sont moins sensibles aux variations environnementales et sélectionnent sans doute des sites de nidification en fonction de la qualité du mâle ou du territoire. Aux fins de conservation, nous études indiquent que le maintien d'un niveau d'eau stable, l'aménagement à faible intensité et l'élimination des perchoirs de coucous sont vraisemblablement susceptibles de profiter tant aux mâles qu'aux femelles aux longues ailes.

Key Words: brood parasitism; ecological trap; niche segregation; reed habitat; reed management; sex-related habitat selection 


\section{INTRODUCTION}

How animals choose their habitats is a central question in ecology and conservation, and birds provide probably the best model system to study animal habitat choice. Habitat choice in birds can be interpreted at various spatial (geographic range, home range, site, distribution of resources, e.g., food availability) and temporal (breeding, migrating, wintering) scales (Johnson 1980) and is strongly related to the morphological and physiological properties of the individuals, populations, and species (Block and Brennan 1993). Although bill morphology has been central in numerous studies of habitat choice, resource use, and niche partitioning in birds (Grenier and Greenberg 2005, Duijns et al. 2014), less attention has been paid to the hypothesis that habitat choice may depend on wing morphology (Vanhooydonck et al. 2009, Saino et al. 2017). Certain habitats may select for certain wing morphology, e.g., short, rounded wings may be more beneficial in structurally diverse habitats that require good manoeuvering abilities (Kaboli et al. 2007), whereas large, pointed wings may be more beneficial in less diverse habitats in which the energy efficiency or the speed of flight may be more important, e.g., to escape from predators (Vanhooydonck et al. 2009). The relationship between wing morphology and environment/habitat remains poorly understood because selection on wing morphology depends on annual variation in weather and related changes in the environment (Vanhooydonck et al. 2009), on ecological factors such as primary production and habitat structural diversity (Saino et al. 2017), and on the quality, age, and sex of the individuals (Fernández and Lank 2007).

The difference in the responses of sexes to certain ecological factors have long been known as intersexual niche segregation (Selander 1966). For example, females of the Sparrowhawk (Accipiter nisus) specifically hunt larger, pigeon-sized prey, whereas males hunt smaller-sized prey, thus the two sexes exploit different ecological niches (Newton 1986). Sex-dependent differences in habitat preference may arise because of the different body morphology (sexual dimorphism), fitness components (survival and reproduction), and food preference of the sexes, which will be reflected in their responses to habitat diversity, vegetation structure, landscape composition, and food availability (Gerritsen et al. 2010, Mancini et al. 2013). Sex-related differences in habitat preference in birds have been studied mostly during the nonbreeding period. For example, males of the Hooded Warbler (Wilsonia citrina) select different vegetation types than females (Morton 1990). American Kestrel (Falco sparverius) females occupy more open habitats for hunting than males (Ardia and Bildstein 1997). In the globally threatened King Rail (Rallus elegans), females have larger home ranges than males (Kolts and McRae 2017). In contrast, our knowledge on sexrelated habitat preference in birds during the breeding period remains scarce. For example, in the polygynous Bengal Florican (Houbaropsis bengalensis), males prefer habitats associated with low-intensity human activity, whereas females prefer undisturbed habitats (Gray et al. 2009).

The Great Reed Warbler (Acrocephalus arundinaceus, hereafter GRW) is a long-distance migratory bird, and migration selects for long, pointed wings for better energy use and enhanced speed. Long-winged, probably older, males arrive back to the breeding grounds earlier and occupy territories in the presumably highestquality habitats, and later-arriving, usually younger, males probably settle in habitats of lower quality (Hasselquist 1998, Leisler and Schulze-Hagen 2011). In a previous comparison of male wing size over six habitat types (Mérö et al. 2016), we found that male wing length was highest along large canals (presumed high-quality habitats), intermediate in mining ponds and middlesized canals, and was lowest in marshes and small canals. We also found evidence that reed (Phragmites australis) habitats attractive to males were those with deep, stable water and little reed management (Mérö et al. 2016). Habitat choice by females may correspond to or contradict these patterns. If there is assortative mating, or if a female chooses to mate with an already mated male (polygyny), wing-size differences among habitats will be similar to that of males. In contrast, differences in wing-size patterns between habitat types will be different from that found for males if mating is dissortative or if females tend to choose nonmated males. In addition, female habitat choice will likely depend on the quality of the habitat types available for nesting, as predicted by the polygyny threshold model (Orians 1969). The quality of the reed habitats of the GRW is determined mainly by fluctuations in water level and by reed management (reed harvesting, burning), which influence reed density and the availability of old reed stems preferred by GRW for nesting (Graveland 1998, Batáry and Báldi 2005, Mérő et al. 2014, 2016). Habitat quality is also considerably influenced by nest parasitism by Common Cuckoos (Cuculus canorus, hereafter Cuckoo) and by nest predation (Moskát et al. 2008, Koleček et al. 2015), and both factors are known to vary in strength among reed-habitat types (Mérő et al. 2015a). A full evaluation of habitat preference and its relationship with wing morphology thus needs to consider both reed management and habitat quality.

The aim of our study was to evaluate whether and how habitat choice is influenced by individual quality and/or by habitat quality in female GRW. To characterize individual quality, we measured wing length, which is widely used as a proxy for individual quality in ecological studies of passerine birds (Nowakowski 2000, Forstmeier et al. 2001) because it provides the best general measure of body size in field measurements of passerine birds (Gosler et al. 1998). Regarding habitat quality, we hypothesized that long-winged females tend to choose habitats with deep, stable water with intermediate reed density and little management, and low Cuckoo parasitism and nest predation (based on Koleček et al. 2015 and Mérő et al. 2016). We used a large dataset on wing length of GRWs nesting in six different wetland habitat types and data on habitat management collected over a period of 10 years to address our study goals.

\section{METHODS}

\section{Conservation status and trend of study species}

The GRW is often considered a flagship species of lowland temperate reed wetlands (Horns et al. 2016) and is a good indicator of reed habitats because of its dependence on reed-bed quality (Mérő et al. 2015b). A large-scale declining trend of GRW was reported in Europe in the 1970s and 1980s (Hagemeijer and Blair 1997), however the species is currently listed as Least Concern (IUCN 2016). In the study area, the population trend of the species is relatively stable, apart from minor interannual fluctuations (Mérő and Žuljević 2017). Both reed management 
and water management influence habitat and nest site selection (Graveland 1998, Mérö et al. 2016) and breeding success (Mérő et al. 2014). The water level near the nests affects nestling survival significantly (Mérő et al. 2015a), and inappropriate water management and reed die-back can result in a rapid decline of breeding populations (Graveland 1998). For example, in the Netherlands, the GRW breeding population has declined from $\mathrm{c}$. 10,000 pairs in the 1950 s to c. 200 pairs in 2008 due to inappropriate water management (van Turnhout et al. 2010).

\section{Study area}

The study sites ( $\mathrm{n}=32$ sites) represented six types of reed habitat in the region of Sombor $\left(1178 \mathrm{~km}^{2} ; 45^{\circ} 47^{\prime} 03^{\prime \prime} \mathrm{N}, 19^{\circ} 05^{\prime} 49^{\prime \prime} \mathrm{E}\right.$, NW Serbia): mining ponds, marshes, large canals, and three size classes of small canals (Fig. 1; Table 1). Sombor is an intensive agricultural region with an extensive network of canals, a few mining ponds, and remnant marshes as reed wetland habitats. For this study, we selected all mining ponds and marshes suitable for GRW nesting and also selected canal sections with suitable habitat, defined as continuous reed stands at least $2 \mathrm{~m}$ wide, randomly in each study year. The minimum distance between sites belonging to different habitat types was $1.5 \mathrm{~km}$.

Fig. 1. The sampled canal sections (stripes), marshes (stars), and mining ponds (triangles) in the region of Sombor, NW Serbia. Canal sections were selected randomly for study in each year, and the figure shows all sections in which fieldwork was conducted in any of the 10 study years.

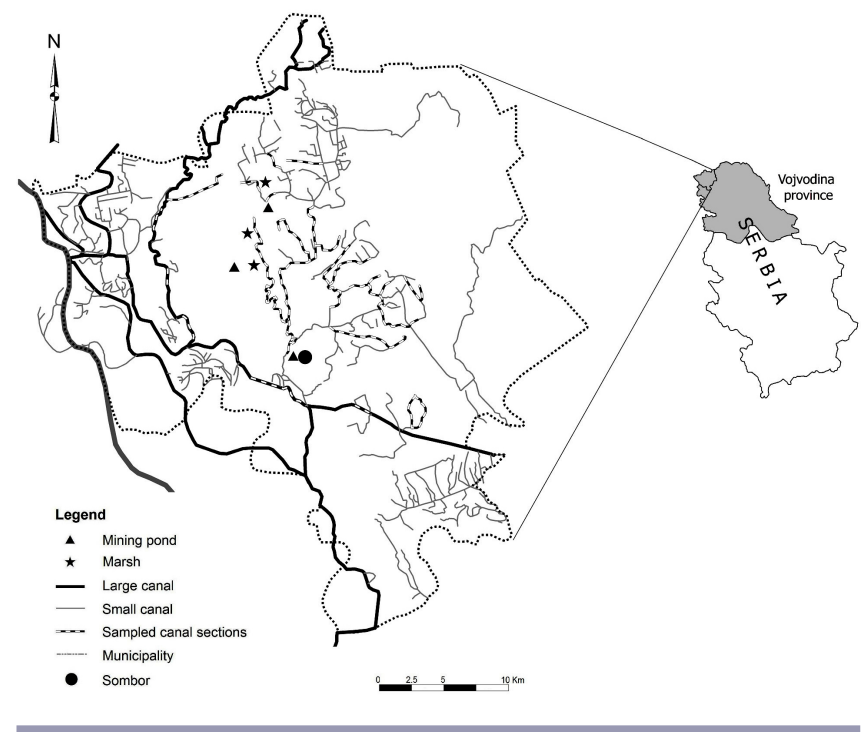

The mining ponds ( $\mathrm{n}=3$ sites) were former sources of clay for the local brickyards that functioned until 1967. Their surface area is between 0.7 to 2.0 ha and is covered with patchy, fragmented, or closed, homogeneous reed beds. Water level fluctuates based on the amount of precipitation in the winter and spring seasons and on the ground-water table, which usually decreases throughout the summer and early autumn droughts. During February and March, the locals often burn parts of the reed beds (Mérö et al. 2018). Shrubs and/or trees growing near the banks provide potential perches for Cuckoos.
The marshes $(n=3)$ are remnants of winding and sluggish lowland rivers. The size of these marshes varies between 2 and 13.5 ha and are usually covered by closed and often homogeneous reed stands. The water level depends strongly on the amount of precipitation. Because of high temperatures, water generally disappears in June. Potential perches for Cuckoos were at least $20 \mathrm{~m}$ away from the marshes. Marshes are practically not managed (Mérő et al. 2018).

The large canals ( $n=4$; total length of sampled sections $10.6 \mathrm{~km}$ ) vary between $15-35 \mathrm{~m}$ in width and their banks are covered with 2 to 6-m-wide reed strips. The reed strips are sporadically interspersed with Typha, Carex, or Salix species. The water level is usually stable because of active regulation through a sluice system and some sections of reed stands are managed by burning and moving once every few years (Mérö et al. 2018). Along the banks on both sides, a forest belt provides many good and close perches for Cuckoos.

Small canals were classified into three size classes according to the categorization of the local water-management company. The classification was based on the width, drainage capacity, and area of the water catchment basin of the canals. The small canals I ( $\mathrm{n}$ $=5$; total length of surveyed sections: $22.7 \mathrm{~km}$ ) are usually deep and vary in width between 4 and $6 \mathrm{~m}$. Here, the reed beds are located in patches on one or both sides and are usually mowed in late summer. Mowing was replaced by vegetation removal in 2015 , when reed stalks were removed completely. Management is applied in the autumn or winter once a year or in every other year, depending on the needs of water management. Occasional Cuckoo perches are solitary shrubs, trees, electric wires, or high banks of the canal (Moskát and Honza 2000). The width of small canals II $(\mathrm{n}=12 ; 41.2 \mathrm{~km})$ varies from 2 to $4 \mathrm{~m}$, and patchy reed stands stretch over the canal channel. Small canals II were characterized by intermediate water depth, and intermediate decrease of the water level during the breeding season (Table 1). The irregularly managed reed was more often burned than mown, on one or both sides. Potential perches for Cuckoos were similar to those near small canals I. Finally, small canals III ( $n=5 ; 10.5$ $\mathrm{km}$ ) are shallow, vary in width from 1 to $3 \mathrm{~m}$, and contain patchy reed beds, which are rarely mown. These shallow canals dried out by late May or early June. Potential perches for Cuckoos are rare and far from the canal. For further details about the reed habitats, see Mérő et al. (2016, 2018).

\section{Sampling}

Fieldwork was conducted from April to August for 10 years (2010-2019). We only considered breeding females, defined as a bird either incubating eggs in a nest, feeding young, and/or defending a nest. Females on migration were not considered. We captured females with mist nets near or farther away from the nests, using the strategy of cutting off their feeding routes with several mist nets in the advanced nestling stage when feeding activity was high.

Females were captured, color-banded, and measured in May to mid-June, which minimized the chances that feather wear, which usually occurs from late June and in July, influenced our wing length measurements. The GRWs finish moulting in February and have fresh feathers when they arrive back from the wintering grounds in late April and early May. Captured females were banded with aluminum and color rings. We measured the total 
Table 1. Mean \pm SD values of reed density, proportion of managed reed, and water variables for the six studied reed habitats, based on data combined from the 10 years.

\begin{tabular}{|c|c|c|c|c|c|c|}
\hline \multirow[t]{2}{*}{ Reed habitat (n) } & \multicolumn{6}{|c|}{ Mean values (mean \pm SD) } \\
\hline & $\begin{array}{c}\text { Mixed reed density } \\
\text { at the nest } \\
\left(\mathrm{m}^{-2}\right)\end{array}$ & $\begin{array}{c}\text { Proportion of } \\
\text { managed reed } \\
(\%)\end{array}$ & $\begin{array}{l}\text { Water depth } \\
\text { (cm) }\end{array}$ & $\begin{array}{c}\text { Fluctuation of } \\
\text { water level }(\mathrm{cm})\end{array}$ & $\begin{array}{c}\text { Proportion of } \\
\text { parasitized nests } \\
(\%)\end{array}$ & $\begin{array}{c}\text { Number of } \\
\text { fledglings / nest }\end{array}$ \\
\hline Mining ponds (3) & $229.8 \pm 25.7$ & $17.6 \pm 31.3$ & $67.3 \pm 19.9$ & $33.9 \pm 20.1$ & $7.1 \pm 8.1$ & $2.2 \pm 0.7$ \\
\hline Marshes (3) & $266.2 \pm 61.3$ & $0.0 \pm 0.0$ & $16.9 \pm 10.1$ & $8.8 \pm 7.0$ & $5.4 \pm 6.2$ & $2.0 \pm 0.8$ \\
\hline Large canals (4) & $194.4 \pm 28.9$ & $6.3 \pm 17.1$ & $102.6 \pm 19.0$ & $5.6 \pm 2.5$ & $39.3 \pm 23.5$ & $0.9 \pm 0.8$ \\
\hline Small canals I (5) & $169.8 \pm 45.0$ & $65.3 \pm 47.4$ & $66.1 \pm 15.9$ & $16.2 \pm 7.5$ & $21.0 \pm 20.7$ & $1.7 \pm 0.6$ \\
\hline Small canals II (12) & $205.6 \pm 31.0$ & $19.8 \pm 36.7$ & $55.6 \pm 24.1$ & $24.6 \pm 9.9$ & $11.7 \pm 13.9$ & $2.0 \pm 0.5$ \\
\hline Small canals III (5) & $187.5 \pm 22.7$ & $0.4 \pm 2.0$ & $22.3 \pm 8.8$ & $22.0 \pm 8.0$ & $10.5 \pm 15.9$ & $1.8 \pm 0.7$ \\
\hline
\end{tabular}

length of the left wing by standardized methods (Svensson 1992) and by using a 150-mm wing ruler (Ecotone Ltd., Gdynia, Poland; accuracy $0.5 \mathrm{~mm}$ ). We only measured wing length when the wing feathers were intact. Earlier studies suggested that wing length is the body measurement with the lowest measurement error $(\%$ variability accounted for by measurement error: < 1\%) and highest consistency (repeatability $>0.99$ ) compared to other standardized body measurements in passerines (Gosler et al. 1998, Goodenough et al. 2010). To minimize observer error, all measurements were taken by TOM. After banding, we used binoculars to confirm that the banded female belonged to the given nest nearby. Breeding females were assigned to the reed habitat in which their nest was located.

We characterized habitat quality by four variables for reed-bed quality and two variables for nest parasitism and predation (Table 1). Each of the six variables were assessed at each study site in each study year. The four variables for reed-bed quality were the proportion of managed reed, density of old and fresh reed, water depth, and fluctuation of water level. We measured the area of managed and nonmanaged parts of the reed beds by using a GPS device. Data on reed density and water variables were collected at 10 nests or at all nests when there were fewer than 10 nests in a reed bed. Nests were searched exhaustively in mining ponds and smaller marshes, whereas in larger marshes, only those parts were searched where mist-netting was possible. Along canals, nests were searched systematically in the sections selected randomly by walking on both banks or from a boat. Nests were monitored once every five days to infer nest fate and/or the number of chicks surviving to fledging from the nest. We usually found nests with complete clutches well into incubation, when they were no longer attractive to Cuckoos, which, to achieve synchrony with the host, typically search for nests when GRWs build the nest or lay the eggs (Márton et al. 2019). During nest checks, we further minimized the discoverability of the nests by Cuckoos and predators by repositioning reed stalks to restore their density and position at the nest to the status in which we had found them. We determined reed density by counting old and new reed stems in a circle of $50 \mathrm{~cm}$ in diameter $1 \mathrm{~m}$ from the nest in a random direction, and we then extrapolated this to $1 \mathrm{~m}^{2}$. We estimated the density of mixed (old plus new) reed, the habitat typically used by GRW for nesting, in each of the six reed habitats (Table 1). Water depth was measured with a stick (accuracy: $5 \mathrm{~cm}$ ). The fluctuation of the water level was calculated as the difference between maximum and minimum measured water depths during the breeding season. As proxies for nest parasitism and predation, we used the proportion of nests parasitized by Cuckoos and the average number of fledglings per nest per site per year, respectively. The proportion of Cuckoo-parasitized nests was calculated as the number of parasitized nests divided by the total number of nests found in a reed bed (study site; Moskát and Honza 2002). The number of fledglings (Cuckoo fledglings not included) per nest was calculated as the total number of fledglings found in a reed bed divided by the total number of nests found in the reed bed in any given year at each site.

\section{Statistical analysis}

We analyzed differences in wing length between reed-habitat types and tested the effects of habitat variables on wing length by constructing a linear mixed-effects model (LMM). The LMM modeled the relationship between wing length (response variable) and habitat types and the six variables characterizing the quality of reed habitats (fixed effects), with "year" nested within "site" as the random factor. To infer the significance of differences in mean wing length among the habitat types, we calculated the coefficient estimates for each habitat type relative to large canals, in which we expected individuals with the longest wings based on our previous work on male wing length (Mérő et al. 2016). In the full LMM, we also tested the significance of the interactions between habitat types and the habitat variables on wing length. Because none of the interactions were significant ( $p>0.05)$, we present results without the interaction terms for simplicity. Recaptures were excluded from the LMM. We used a chi-square test to check whether the recaptured females (banded as adults) showed philopatry to their initial nesting reed habitat. Finally, we compared wing lengths of birds that were captured and measured in two consecutive years by calculating Pearson's correlation coefficient. The normality of the variables was tested with Shapiro-Wilk tests and the homogeneity of variances was checked with Bartlett tests. Statistical analyses were performed in IBM SPSS Statistics 23.0. (IBM SPSS Inc., Chicago, USA, 2015) and in $\mathrm{R}$ (version 3.6.3., R Core Team 2020).

\section{RESULTS}

We captured and banded a total of 391 females and recaptured $38(9.7 \%)$ of them at least once in the subsequent years. The mean wing length was $95.6 \pm$ (S.D.) $2.12 \mathrm{~mm}$ (range: 89 to $101 \mathrm{~mm}, \mathrm{n}$ $=391$ females) and appeared to vary between habitat types (Fig. 2). The LMM showed that wing length differed significantly between the six habitat types $\left(F_{5,28}=2.700, p=0.039\right.$; Table 2$)$. Coefficient estimates from the LMM suggested that wing length was significantly higher in small canals I $(+2.34 \pm 0.741 \mathrm{~mm})$, 
Table 2. Coefficient estimates from a linear mixed-effects model testing the effects of habitat type, reed-bed quality (four variables) and proportion of Cuckoo parasitism and mean breeding success (fixed effects), and year nested within study site (random factor) on wing length of female Great Reed Warblers. Significant effects are highlighted in bold.

\begin{tabular}{|c|c|c|c|c|}
\hline Variable/comparison & Estimate \pm S.E. & df & $\mathrm{t}$ & $\mathrm{p}$ \\
\hline (Intercept) & $94.01 \pm 1.360$ & 287 & 69.138 & 0.000 \\
\hline Habitat type: Marsh vs. Large canal & $1.86 \pm 0.947$ & 28 & 1.967 & 0.059 \\
\hline Habitat type: Mining pond vs. Large canal & $2.06 \pm 0.759$ & 28 & 2.714 & 0.011 \\
\hline Habitat type: Small canal I vs. Large canal & $2.34 \pm 0.741$ & 28 & 3.154 & 0.004 \\
\hline Habitat type: Small canal II vs. Large canal & $1.67 \pm 0.755$ & 28 & 2.218 & 0.035 \\
\hline Habitat type: Small canal III vs. Large canal & $0.49 \pm 0.981$ & 28 & 0.501 & 0.620 \\
\hline Reed density & $0.00 \pm 0.004$ & 287 & 0.346 & 0.730 \\
\hline Proportion of managed reed & $-0.01 \pm 0.004$ & 64 & -1.713 & 0.092 \\
\hline Water depth & $0.00 \pm 0.007$ & 287 & 0.437 & 0.662 \\
\hline Water-level fluctuation & $-0.02 \pm 0.010$ & 287 & -2.056 & 0.041 \\
\hline Proportion of Cuckoo parasitism & $0.56 \pm 0.934$ & 287 & 0.596 & 0.552 \\
\hline Mean breeding success & $-0.07 \pm 0.207$ & 287 & -0.340 & 0.734 \\
\hline
\end{tabular}

mining ponds $(+2.06 \pm 0.759 \mathrm{~mm})$, and small canals $\mathrm{II}(+1.67$ $\pm 0.755 \mathrm{~mm}$ ) compared to large canals (Table 2). The difference in wing length between females nesting in marshes and large canals was marginally nonsignificant $(\mathrm{p}=0.059)$, and wing length did not differ between small canals III and large canals (Table 2). Wing length was negatively related to water-level fluctuation $\left(F_{1,287}=5.400, p=0.021\right.$; Table 2$)$. Although the proportion of managed reed had a marginally nonsignificant $(\mathrm{p}=0.092)$ negative effect, habitat variables other than water-level fluctuation were not related to wing length (Table 2).

Fig. 2. Boxplot (median, upper, and lower quartiles, min, max) of wing length in the six studied reed habitat types. Original data points (black dots) are jittered for clarity (sample sizes, mining pond: 132 , marsh: 30 , large canal: 16 , small canal 1: 99 , small canal 2: 90 , small canal 3: 24 , total $N=391$ female Great Reed Warblers). Red dots indicate means.

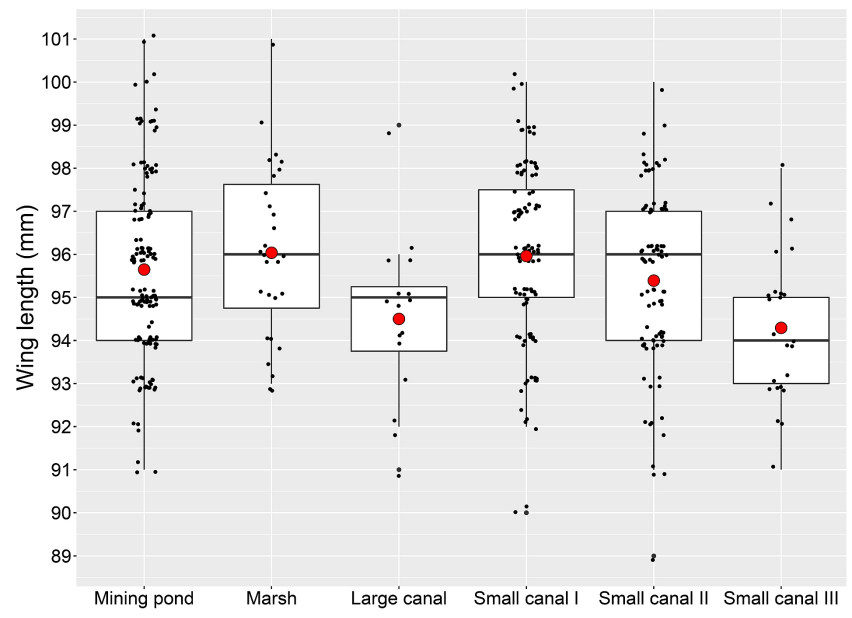

Exactly $50 \%$ of females banded as nestlings $(n=10)$ showed natal philopatry to their reed habitat. Individuals banded as adults ( $\mathrm{n}$ $=28$ ) displayed strong breeding philopatry because $26(93 \%)$ of them returned in 1 or more subsequent years to the reed habitat they had been observed to breed in the year of capture, which differed from a random distribution of individuals among habitat types (chi-square test, $\chi^{2}=15.08, \mathrm{df}=4, \mathrm{p}=0.004$ ). The wing length measurements taken on birds recaptured in the year following the year of the first capture were highly correlated (Pearson $\mathrm{r}=0.832, \mathrm{n}=15, \mathrm{p}=0.0001$ ).

\section{DISCUSSION}

We found evidence that wing length of female GRWs can differ among habitat types because more longer-winged females nested on medium-sized canals (small canals I and II) and mining ponds than on large canals and the smallest canals (small canals III). The differences between pairs of habitat types were larger (maximum difference $>2 \mathrm{~mm}$ ) when other variables potentially influencing wing length (year, site, habitat variables) were accounted for in the LMM than what could be inferred based on the raw data only (maximum difference $\approx 1.5 \mathrm{~mm}$; Fig. 2). Although these differences may appear small, they exceed $2 \%$ of total wing length. A difference of a few $\mathrm{mm}$ is likely important for the shape of the wing and can have consequences on the maneuvering ability of birds in a highly structured habitat such as a dense reed beds and on the flight ability of birds during longdistance migration from Central Europe to sub-Saharan Africa. In the congeneric Reed Warbler (Acrocephalus scirpaceus), the differences are even smaller and were demonstrated to have consequences on habitat selection and individual competitive ability (Nowakowski 2000). The differences between habitat types may be partly interpreted with consideration to the trade-off between wing length and maneuvering ability (Videler 2005, Kaboli et al. 2007, Vanhooydonck et al. 2009). This trade-off suggests that longer, more pointed wings can be more suitable in more open or looser habitats, such as the managed mining ponds and medium-sized canals in this study. Moreover, shorter, more rounded wings can be more suitable in more structured or cluttered habitats, such as small canals III in our study. Such differences in wing length and shape were associated with differences in feeding behavior between the sexes in the Willow Warbler, Phylloscopus trochilus (Nyström 1991).

We also found evidence that wing length-related habitat choice in females is less sensitive to environmental variables than that in 
males. In males, wing length was related to the proportion of managed reed, water depth and fluctuation of water depth, and an interaction between the proportion of managed reed and water depth (Mérö et al. 2016), whereas in females, it was related only to water-level fluctuation (this study). This is plausible because in GRW, males usually arrive from the wintering grounds earlier than females do and males make the primary choice of nesting habitat by occupying territories (Hasselquist 1998). Females that choose males and/or territories can thus only select nesting habitat from what males already have chosen, i.e., from an environmentally filtered subset of all available nesting habitats. It is thus not surprising that wing-length related habitat choice in females was related only to water-level fluctuation.

A more detailed comparison of the results of this study and those of our previous study of wing size-related habitat choice in males (Mérö et al. 2016) suggests both similarities and differences in habitat choice between the sexes. Wing length was negatively related to fluctuation of water level in both sexes, indicating that longer-winged individuals probably formed pairs in sites with more stable water. However, in males, large canals were the habitat type occupied by males of the longest wings, whereas in females, longest-winged individuals were found in mining ponds and small canals I and II (medium-sized canals), and wing length was significantly smaller in large canals than in these habitats. In both sexes, mean wing length was smallest in the smallest canals, indicating that these habitats may be the least attractive to longerwinged individuals.

These differences are probably related to the timing of the arrival of individuals from the wintering to the breeding grounds. In our study area, males arrive in late April and early May, when only old reed from previous years is available for singing and occupying territories. Old reed is available only in nonmanaged or littlemanaged reed habitats such as marshes and large canals (Table 1). Because GRW males prefer territories on reed edges near openwater surfaces, large canals with little management, abundant old reed, and extensive reed-water edges are obviously attractive to males (Leisler et al. 1989, Mérő et al. 2016). Long-winged, presumably older and dominant males may be better competitors for these territories than smaller-winged, younger males, many of which also arrive at the breeding grounds later than the older males. Shorter-winged males may thus settle in suboptimal areas left vacant by the longer-winged males (Hasselquist 1998).

Females arrive later, in mid May, when newly grown fresh reed stems also become available. Although the males make the primary choice of habitats and territories, females are likely to consider the quality of the male and the nesting habitat occupied (Bensch 1996). But why do long-winged females avoid nesting on the large canals, which are preferred by long-winged males, and why do they prefer medium-sized canals and mining ponds? There may be two plausible explanations for these differences. The first explanation is related to the high pressure of nest parasitism by Cuckoos, which was highest (39\%; Table 1) at large canals of the six habitat types. Dominant, presumably older and longer-winged females avoid nesting in habitats in which they fledged a Cuckoo young in a previous season (Koleček et al. 2015), leaving these habitats available for the shorter-winged, later arriving, and probably younger females. This explanation is supported by our recapture and resight data, namely, that we have never recaptured females in the suspected poor habitats (large canals and small canals III) from previous years, whereas in habitats that were occupied by intermediate and long-winged females, several individuals were recaptured or resighted in the subsequent years (Mérö et al. 2018). This suggests that the high pressure of Cuckoo parasitism at large canals dis-attracts long-winged females, despite the otherwise good nesting conditions, e.g., little fluctuation of water levels (Table 1).

A second potential explanation is related to dominance patterns and competition for food. In reed habitats with a high nesting density (mining ponds, small canals I and II), competition for food may be more intense, and longer-winged, probably more dominant females may be better competitors than smaller females. In a smaller-bodied congeneric species, the Reed Warber, short-winged females are indeed poorer competitors than longwinged females (Nowakowski 2000). Longer-winged females may thus be more efficient than short-winged females at retrieving food farther from the nest and during longer feeding bouts in high-competition habitats during chick rearing. In habitats where competition is less intense, short-winged females may be able to find enough food in the vicinity of the nest, benefitting from closer distances and shorter feeding bouts during chick rearing, which can be particularly important in periods of food shortages such as rainy and cold periods (Nowakowski 2000).

One important difference in habitat choice between the sexes was that reed management strongly determined habitat choice in males but not in females. Male wing length was negatively related to the proportion of managed reed and fluctuation of water level, indicating that longer-winged males preferred reed habitats with little management and stable water level (Mérö et al. 2016). Stable water levels are important both for nest protection (e.g., against terrestrial predators), and the opportunity of renesting (Kluyver 1955, Mérő et al. 2016). Although reed management did not significantly influence wing length in females, it is worth noting that the proportion of managed reed was relatively high in the three habitat types in which long-winged females nested (mining ponds, small canals I and II; Fig. 2; Table 1). Managed, sparse reed probably provides better opportunities for maneuvering than dense reed in nonmanaged or little-managed reed habitats (Poulin et al. 2002). Easier maneuverability between reed stems is particularly important in the chick-rearing period, and females in nonmanaged, dense reed need excellent maneuvering skills during foraging and the feeding of the young (Bensch 1996, Sejberg et al. 2000). Managed reed habitats can also have higher insect abundance than nonmanaged habitats (Trnka et al. 2014), which can also explain why longer-winged, possibly dominant, females chose more managed areas. Finally, less dense reed also allows a nest-building or incubating female to better notice the approach of potential predators.

Understanding the background and functioning of sex-specific segregation in habitat choice in different species can have an important role in the development of conservation strategies (Safi et al. 2007). Intersexual differences in habitat choice can also have important consequences for population persistence if habitat variables preferred by sexes are disproportionately influenced by changes in habitat structure (Ruckstuhl and Neuhaus 2006). The main conservation implication of our results is that water management, where possible, should provide stable water level 
Avian Conservation and Ecology 15(1): 22

http://www.ace-eco.org/vol15/iss1/art22/

through the use of sluice systems to benefit both long-winged males and females. Ideally, water levels should be set before the arrival of GRW from the wintering grounds and maintained until the end of the breeding season. Furthermore, based on this study and Mérő et al. (2016), we suggest that a low intensity of management (e.g., proportion of managed reed $\approx 20 \%$; Table 1 ) is likely to benefit both long-winged males and females. For example, in linear reed habitats such as canals, reed management may be applied only on one of the riverbanks. In the long term, alternating management on the two sides annually or bi-annually can be suggested. In marshes and mining ponds, reed management should be applied in patches. However, to maintain genetic diversity, i.e., sustaining both long-winged and shorter-winged individuals in a population, the maintenance of a gradient of habitat types ranging from simple, open habitats to more structured, closed habitat types appears appropriate. Finally, management should target potential ecological traps (attractive sites with suboptimal conditions for breeding; Kokko and Sutherland 2001, Battin 2004), suspected in habitats along large canals (Mérö et al. 2015a), to mitigate their effects at the population level. For example, little or no management of reed habitats along with a modification of the surrounding landscape with the aim to decrease the availability of Cuckoo perching sites could be important. In other, nonmanaged sites with low Cuckoo parasitism such as marshes, careful reed management could be implemented to increase their attractiveness to females, e.g., by creating openings or by decreasing reed density.

In conclusion, our study shows that the wing length of female GRWs can differ between reed habitat types because it was highest in mining ponds and medium-sized canals, and it was lowest in the largest and the smallest canals. Water-level fluctuation negatively influenced the habitat choice of both males and females, indicating the importance of stable water levels. Although reed management influenced the habitat choice of males (Mérő et al. 2016), it was less important to females, which likely make nesting site choices based on the quality of the male or of his territory. A more detailed understanding of these differences based on food availability, i.e., the spatial and temporal distribution of food resources, landscape composition and structure, and land use will provide further knowledge for the conservation of wetland species and ecosystems.

Responses to this article can be read online at:

http://www.ace-eco.org/issues/responses.php/1571

\section{Acknowledgments:}

We thank Dora Malbaša and Ivana Šećerov for their help during the field work. This study was supported by the Foundation EuroNatur, Radolfzell, Germany (grant numbers SR-11-215-02 and RS-13-889-02), and by three grants from the National Research, Development and Innovation Office of Hungary (NKFIH-OTKA PD128002, K106133, GINOP 2.3.3-15-2016-00019). Birds were handled in accordance with the rule book of the Centre for Animal Marking, Natural History Museum, Belgrade, Serbia. We thank to the Public Water-management Company "Zapadna Bačka" for their cooperation. The authors declare that they have no competing interests.

\section{LITERATURE CITED}

Ardia, D. R., and K. L. Bildstein. 1997. Sex-related differences in habitat selection in wintering American Kestrels, Falco sparverius. Animal Behavior 53:1305-1311. https://doi.org/10.1006/anbe.1996.0364

Batáry, P., and A. Báldi. 2005. Factors affecting the survival of real and artificial Great Reed Warbler's nests. Biologia 60:215-219.

Battin, J. 2004. When good animals love bad habitats: ecological traps and the conservation of animal populations. Conservation Biology 18:1482-1491. https://doi.org/10.1111/j.1523-1739.2004.00417. $\mathrm{x}$

Bensch, S. 1996. Female mating status and reproductive success in the Great Reed Warbler: is there a potential cost of polygyny that requires compensation? Journal of Animal Ecology 65:283-296. https://doi.org/10.2307/5875

Block, W. M., and L. A. Brennan. 1993. The habitat concept in ornithology: theory and applications. Current Ornithology 11:35-91. https://doi.org/10.1007/978-1-4757-9912-5_2

Duijns, S., J. A. van Gils, B. Spaans, J. ten Horn, M. Brugge, and T. Piersma. 2014. Sex-specific winter distribution in a sexually dimorphic shorebird is explained by resource partitioning. Ecology and Evolution 4:4009-4018. https://doi.org/10.1002/ ece 3.1213

Fernández, G., and D. B. Lank. 2007. Variation in the wing morphology of Western Sandpipers (Calidris mauri) in relation to sex, age class, and annual cycle. Auk 124:1037-1046. https:// doi.org/10.1093/auk/124.3.1037

Forstmeier, W., O. V. Bourski, and B. Leisler. 2001. Habitat choice in Phylloscopus warblers: the role of morphology, phylogeny and competition. Oecologia 128:566-576. https://doi.org/10.1007/ s004420100678

Gerritsen, H. D., D. McGrath, C. Lordan, and X. Harlay. 2010. Differences in habitat selection of male and female megrim (Lepidorhombus whiffiagonis Walbaum) to the west of Ireland. A result of differences in life-history strategies between the sexes? Journal of Sea Research 64:487-493. https://doi.org/10.1016/j. seares.2010.01.011

Goodenough, A. E., R. Stafford, C. L. Catlin-Groves, A. L. Smith, and A. G. Hart. 2010. Within and among-observer variation in measurements in animal biometric and their influence on accurate quantification of common biometric-based condition indices. Annales Zoologici Fennici 47:323-334. https://doi. org/10.5735/086.047.0503

Gosler, A. G., J. J. D. Greenwood, J. K. Baker, and N. C. Davidson. 1998. The field determination of body size and condition in passerines: a report to the British Ringing Committee. Bird Study 45:92-103. https://doi.org/10.1080/00063659809461082

Graveland, J. 1998. Reed die-back, water level management and the decline of the Great Reed Warbler Acrocephalus arundinaceus in The Netherlands. Ardea 86:187-201.

Gray, T. N. E., H. Chamnan, N. J. Collar, and P. M. Dolman. 2009. Sex-specific habitat use by a Lekking Bustard: conservation implications for the critically endangered Bengal Florican (Houbaropsis bengalensis) in an intensifying agroecosystem. Auk 126:112-122. https://doi.org/10.1525/auk.2009.08023 
Grenier, J. L., and R. Greenberg. 2005. A biogeographic pattern in sparrow bill morphology: parallel adaptation to tidal marshes. Evolution 59:1588-1595. https://doi.org/10.1111/j.0014-3820.2005. tb01808.x

Hagemeijer, W. J. M., and M. J. Blair. 1997. The EBCC atlas of European breeding birds: their distribution and abundance. T \& AD Poyser, London, UK.

Hasselquist, D. 1998. Polygyny in the Great Reed Warbler: a longterm study of factors contributing to male fitness. Ecology 79:2376-2390. https://doi.org/10.1890/0012-9658(1998)079[2376: PIGRWA]2.0.CO;2

Horns, J. J., E. Buechley, M. Chynoweth, L. Aktay, E. Çoban, M. A. Kırpık, J. M. Herman, Y. Şaşmaz, and Ç. H. Şekercioğlu. 2016. Geolocator tracking of Great Reed Warblers (Acrocephalus arundinaceus) identifies key regions for migratory wetland specialists in the Middle East and sub-Saharan East Africa. Condor: Ornithological Applications 118:835-849. https://doi. org/10.1650/CONDOR-16-63.1

International Union for Conservation of Nature (IUCN). 2016. Red list of threatened species. Version 2016-3. International Union for Conservation of Nature, Cambridge, UK. [online] URL: http://www.iucnredlist.org

Johnson, D. H. 1980. The comparison of usage and availability measurements for evaluating resource preference. Ecology 61:65-71. https://doi.org/10.2307/1937156

Kaboli, M., M. Aliabadian, and R. Prodon. 2007. Niche segregation, behavioural differences and relation to morphology in two Iranian syntopic wheatears: the Northern Wheatear Oenanthe oenanthe libanotica and Mourning Wheatear O. lugens persica. Vie et Milieu - Life and Environment 57:137-148.

Kluyver, H. N. 1955. Das Verhalten des Drosselrohrsängers, Acrocephalus arundinaceus (L.), am Brutplaz, mit besonderer Berücksichtigung der Nestbautechnik und der Revierbehauptung. Ardea 43:1-50. (in German)

Kokko, H., and W. J. Sutherland. 2001. Ecological traps in changing environments: ecological and evolutionary consequences of a behaviourally mediated Allee effect. Evolutionary Ecology Research 3:537-551. [online] URL: http://evolutionary-ecology. com/abstracts/v03n05/eear1308.pdf

Koleček, J., V. Jelínek, M. Požgayová, A. Trnka, P. Baslerová, M. Honza, and P. Procházka. 2015. Breeding success and brood parasitism affect return rate and dispersal distances in the Great Reed Warbler. Behavioral Ecology and Sociobiology 69:1845-1853. https://doi.org/10.1007/s00265-015-1997-7

Kolts, J. R., and S. B. McRae. 2017. Seasonal home range dynamics and sex differences in habitat use in a threatened, coastal marsh bird. Ecology and Evolution 7:1101-1111. https://doi. org/10.1002/ece3.2761

Leisler, B., H.-W. Ley, and H. Winkler. 1989. Habitat, behaviour and morphology of Acrocephalus warblers: an integrated analysis. Ornis Scandinavica 20:181-186. https://doi.org/10.2307/3676911

Leisler, B., and K. Schulze-Hagen. 2011. The Reed Warblers: diversity in a uniform bird family. KNNV, Zeist, The Netherlands. https://doi.org/10.1163/9789004278028
Mancini, P. L., A. L. Bond, K. A. Hobson, L. S. Duarte, and L. Bugoni. 2013. Foraging segregation in tropical and polar seabirds: testing the intersexual competition hypothesis. Journal of Experimental Marine Biology and Ecology 449:186-193. https:// doi.org/10.1016/j.jembe.2013.09.011

Márton, A., A. Fülöp, K. Ozogány, C. Moskát, and M. Bán. 2019. Host alarm calls attract the unwanted attention of the brood parasitic Common Cuckoo. Scientific Reports 9:18563. https:// doi.org/10.1038/s41598-019-54909-1

Mérő, T. O., A. Žuljević, K. Varga, R. Bocz, and S. Lengyel. 2014. Effect of reed burning and precipitation on the breeding success of Great Reed Warbler, Acrocephalus arundinaceus, on a mining pond. Turkish Journal of Zoology 38:622-630. https://doi. org/10.3906/zoo-1311-54

Mérő, T. O., A. Žuljević, K. Varga, and S. Lengyel. 2015a. Habitat use and nesting success of the Great Reed Warbler (Acrocephalus arundinaceus) in different reed habitats in Serbia. Wilson Journal of Ornithology 127:477-485. https://doi.org/10.1676/13-200.1

Mérő, T. O., L. Lontay, and S. Lengyel. 2015b. Habitat management varying in space and time: the effects of grazing and fire management on marshland birds. Journal of Ornithology 156:579-590. https://doi.org/10.1007/s10336-015-1202-9

Mérő, T. O., A. Žuljević, K. Varga, and S. Lengyel. 2016. Wing size-related reed habitat selection by Great Reed Warbler (Acrocephalus arundinaceus) males. Auk: Ornithological Advances 133:205-212. https://doi.org/10.1642/AUK-15-175.1

Mérö, T. O., and A. Žuljević. 2017. Nest position and reed density influence nest defence behaviour of Great Reed Warbler. Ethology, Ecology and Evolution 29:94-101. https://doi. org/10.1080/03949370.2015.1081295

Mérő, T. O., A. Žuljević, K. Varga, and S. Lengyel. 2018. Reed management influences philopatry to reed habitats in the Great Reed Warbler (Acrocephalus arundinaceus). Condor: Ornithological Applications 120:94-105. https://doi.org/10.1650/CONDOR-17-114.1

Morton, E. S. 1990. Habitat segregation by sex in the Hooded Warbler: experiments on proximate causation and discussion of its evolution. American Naturalist 135:319-333. https://doi. org/10.1086/285048

Moskát, C., and M. Honza. 2000. Effect of nest and nest site characteristics on the risk of Cuckoo Cuculus canorus parasitism in the Great Reed Warbler Acrocephalus arundinaceus. Ecography 23:335-341. https://doi.org/10.1111/j.1600-0587.2000.tb00289.x

Moskát, C., and M. Honza. 2002. European Cuckoo Cuculus canorus parasitism and host's rejection behaviour in a heavily parasitized Great Reed Warbler Acrocephalus arundinaceus population. Ibis 144:614-622. https://doi.org/10.1046/

j.1474-919X.2002.00085.x

Moskát, C., B. Hansson, L. Barabás, I. Bártol, and Z. Karcza. 2008. Common Cuckoo Cuculus canorus parasitism, antiparasite defence and gene flow in closely located populations of Great Reed Warblers Acrocephalus arundinaceus. Journal of Avian Biology 39:663-671. https://doi.org/10.1111/j.1600-048X.2008.04359. $\mathrm{x}$

Newton, I. 1986. The Sparrowhawk. T \& AD Poyser, Calton, Staffordshire, UK. 
Nowakowski, J. J. 2000. Long-term variability of wing length in a population of the Reed Warbler Acrocephalus scirpaceus. Acta Ornithologica 35:173-182. https://doi.org/10.3161/068.035.0210

Nyström, K. G. K. 1991. On sex-specific foraging in the Willow Warbler, Phylloscopus trochilus. Canadian Journal of Zoology 69:462-470. https://doi.org/10.1139/z91-072

Orians, G. H. 1969. On the evolution of mating systems in birds and mammals. American Naturalist 103:589-603. https://doi. org/10.1086/282628

Poulin, B., G. Lefebvre, and A. Mauchamp. 2002. Habitat requirement of passerines and reed bed management in southern France. Biological Conservation 107:315-325. https://doi. org/10.1016/S0006-3207(02)00070-8

R Core Team. 2020. R: a language and environment for statistical computing. R Foundation for Statistical Computing, Vienna, Austria. [online] URL: https://www.r-project.org/

Ruckstuhl, K. E., and P. Neuhaus. 2006. Sexual segregation in vertebrates: ecology of the two sexes. Cambridge University Press, Cambridge, UK. https://doi.org/10.1017/CBO9780511525629

Safi, K., B. König, and G. Kerth. 2007. Sex differences in population genetics, home range size and habitat use of the Particolored Bat (Vespertilio murinus, Linnaeus 1758) in Switzerland and their consequences for conservation. Biological Conservation 137:28-36. https://doi.org/10.1016/j.biocon.2007.01.011

Saino, N., R. Ambrosini, M. Caprioli, F. Liechti, A. Romano, D. Rubolini, and C. Scandolara. 2017. Wing morphology, winter ecology, and fecundity selection: evidence for sex-dependence in Barn Swallows (Hirundo rustica). Oecologia 184:799-812. https:// doi.org/10.1007/s00442-017-3918-0

Sejberg, D., S. Bensch, and D. Hasselquist. 2000. Nestling provisioning in polygynous Great Reed Warblers (Acrocephalus arundinaceus): do males bring larger prey to compensate for fewer visits? Behavioral Ecology and Sociobiology 47:213-219. https:// doi.org/10.1007/s002650050658

Selander, R. K. 1966. Sexual dimorphism and differential niche utilization in birds. Condor 68:113-151. https://doi.org/10.2307/1365712

Svensson, L. 1992. Identification guide to European passerines. Fourth, revised and enlarged edition. British Trust for Ornithology, Thetford, UK.

Trnka, A., V. Peterková, P. Prokop, and P. Batáry. 2014. Management of reed beds: mosaic reed cutting does not affect prey abundance and nest predation rate of reed passerine birds. Wetland Ecology and Management 22:227-234. https://doi. org/10.1007/s11273-013-9325-3

Vanhooydonck, B., A. Herrel, A. Gaberla, and J. Podos. 2009. Wing shape variation in the Medium Ground Finch (Geospiza fortis): an ecomorphological approach. Biological Journal of the Linnean Society. 98:129-138. https://doi.org/10.1111/ j.1095-8312.2009.01269.x

van Turnhout, C. A. M., E. J. M. Hagemeijer, and R. P. B. Foppen. 2010. Long-term population developments in typical marshland birds in The Netherlands. Ardea 98:283-299. https://doi. org/10.5253/078.098.0303

Videler, J. J. 2005. Avian flight. Oxford University Press, Oxford, UK. https://doi.org/10.1093/acprof:oso/9780199299928.001.0001
Editor-in-Chief: Alexander L.Bond Subject Editor: John R.Sauer
Sponsored by the Society of Canadian Ornithologists and Birds Canada

Parrainée par la Société des ornithologistes du Canada et Oiseaux Canada

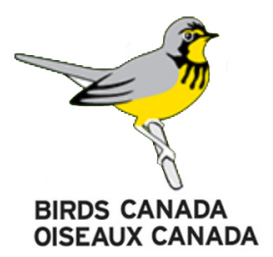

